\title{
PEMAKNAAN JIHAD DAN PROBLEM APLIKASINYA DALAM TATARAN SOSIAL
}

\section{Patompo Adnan*}

\section{Abstract}

The precise meaning of jihad is confusing to even moslem themselves and, let alone, nonmoslem. Many conceive jihad as a sort of physical war against enemies. Jihad also means conquering and subjugating nonmuslims and forcing them to convert to Islamic faith as their religion. But, if we look at in detail the Quranic verses and the hadith, we shall underline that jihad could also be meant as any kind of holding God's commands.

Observing religious practices, helping the poor, being patient and all good deeds are also jibad. Jihad in terms of the war is only allowed when muslims are being attacked by enemies, as what now bappens in Afghanistan and Palestine. The association of jihad with violence, especially after the September 11 attack in the U.S. is a more political trick of the West, especially the U.S., rather than an exact definition of jihad itself.

Keywords: Jihad, Muslim, Nonmuslim, God's Command, War, Violence.

SECARA bahasa jihad berasal dari kata jâhada (جاهد) yujâhidu (يجاهد) mujâhadatan (مجاهدة) jihâdan (جهادا) yang berarti mengerahkan segala kekuatan untuk melakukan sesuatu yang baik atau buruk. Kata mujâhadatan (مجاهدة) atau jihâdan (جهادا), dapat juga bermakna melakukan peperangan untuk menjaga agama dari serangan Asing. Ada kata lain yang serupa, yaitu al-

*Penulis adalah pimpinan Pondok Pesantren Selaparang, berkedudukan di Jln. TGH. Abdul Hafidz Sulaiman Kediri Lombok Barat. e-mail: patompo@telkom.net. 
juhd (الجهد) yang berarti bersungguh-sungguh dalam suatu urusan. Jihad juga berasal dari kata al-jahd (الجَهُ8ُْ8) yang berarti mengerjakan sesuatu dengan penuh kesulitan dan kepayahan. ${ }^{1}$ Pengertian yang sama juga dikemukakan dalam beberapa kamus bahasa Arab, sehingga dapat dianggap cukup untuk dijadikan sebagai starting point pemahamanan tentang makna jihad.

Adapun makna jihad secara istilah adalah memerangi musuh sebagai upaya melindungi agama Islam dan menjaga wilayah teritorial dari gempuran kepungan musuh. ${ }^{2}$ Hasan al-Bannâ memberikan makna jihad dengan makna "kewajiban yang berlangsung terus", sesuai dengan ungkapannya sebagai berikut:

"Jihad adalah kewajiban yang berlaku sampai hari kiamat. Inilah yang dimaksud oleh Rasulullah saw. dalam sabdanya: Barang siapa mati, sementara ia belum pernah berperang dan belum berniat untuk perang, maka ia mati seperti matinya orang jahiliyah. Tingkatan jihad yang paling awal adalah adanya pengingkaran hati (terhadap kemungkaran). Sedang tingkatan tertingginya adalah berperang di jalan Allah. Di antara dua tingkatan sebelumnya itu adalah jihhâd al-lisân (dengan ucapan), jihâad alqalâm (dengan pena), jïhâd al-yad (dengan tangan) dan jihad berupa penyampaian kata-kata yang benar terhadap penguasa yang menyimpang. Dakwah islamiyah tidak dapat eksis kecuali dengan jihad, karena semakin tinggi dan luas medan dakwah islamiyah, maka semakin tinggi pula kadar jihad yang dituntut di jalannya, serta semakin besar pula nilai-nilai perjuangan yang dituntut untuk mendukung jihad yang dilancarkan". 3

${ }^{1}$ Luis Ma'lûf, al-Munjid fî al-Lughah (Beirut: Dâr al-Masyriq, 1977), cet. XXII, 105-6; Attabik Ali dan Ahmad Zuhry Mahdhar, Kamus al'Ashrî (Krapyak Yogyakarta: Multi Karya Grafika, 1998), cet. VII, 648.

'Bahâ' al-Dîn 'Abd al-Rahmân bin Ibrâhim al-Maqdisî, Al-Idah al-Syarn al-

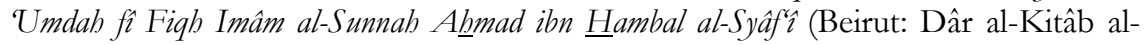
'Arabî, 1414 H/1994),.648;. Ma'lûf, al-Munjid..., 105-6; dan Mahdhar, Kamus..., 648.

${ }^{3}$ Hasan Al-Banna, Surat Terbuka untuk Kader Dakwah, ter. Khozin Abu Faqih (Jakarta: Al-I'tishom, 1992), 22. Kutipan teks aslinya adalah:

و أريد بالجهاد الفريضة الماضية إلى يو القيامة .و المقصو د بقول رسول اله صلى الله عليه وسلم :

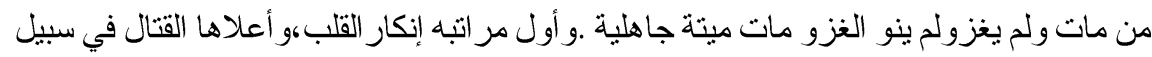


Dari makna bahasa dan istilah itu, maka dapat dipahami bahwa sesungguhnya jihad tidaklah berkonotasi negatif. Jihad bermakna pengerahan segala potensi yang dimiliki dengan tujuan meraih sesuatu yang lebih baik dan mendasar dalam hidup. Jihad juga berarti upaya mempertahankan eksistensi diri dan keberlangsungan hidup dengan mencegah pihak lain berlaku despotik, represif, dan anarkhis terhadap wilayah esensial, substansial, serta fundamental pada area personal dan komunal.

Lebih lanjut dapat ditegaskan bahwa pada dasarnya jihad itu dilakukan untuk memelihara dan mewujudkan hak azasi manusia (HAM), yang kerap menjadi perhatian dan isu global, terutama negara-negara maju seperti Amerika. Sayangnya, konsep HAM yang dimaksudkan Amerika beserta sekutunya, masih sulit dipahami sebagai sesuatu yang positif, sebab yang menjadi ukuran bagi masyarakat bukan pernyataan lisan semata, tetapi substansi dan bukti nyata terhadap pernyataan atas HAM itu. Satu bentuk kesalahan bila jihad dengan segala makna yang dikandungnya diindikasikan sebagai sesuatu yang tidak baik, bahkan sebagai "bahaya laten" bagi peradaban Barat modern. Karena tujuan akhir yang ingin dicapai dan diimplementasikan oleh jihad adalah terbebasnya manusia dari "penghambaan" kepada sesama manusia, dan menghindarkan manusia dari kezaliman dan kesewenang-wenangan pemegang otoritas, yang menjalankan otoritas dengan nafsu bukan dengan ilmu, melepaskan keangkuhan, kesombongan, dan hegemoni suatu bangsa terhadap bangsa lain. ${ }^{4}$

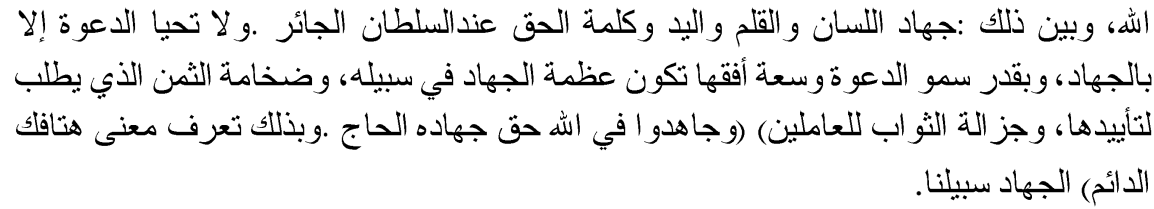

${ }^{4}$ Yusuf Al-Qardhawi, Menuju Kesatuan Fikrah Aktivis Islam, ter. A. Najiyullah (Jakarta: Robbani Press, Agustus 1993), 188-90. 
Oleh karena itu, diperlukan kerangka pemahaman yang benar atas jihad, baik bahasa maupun istilah. Akurasi pemahaman terhadap suatu terminologi seharusnya dijunjung tinggi oleh siapa saja, karena yang demikian itu menjadi aksioma dalam dunia akademik, sebagai upaya tabâyyun (recheck) saat mendengar suatu istilah dilontarkan, agar tidak terjebak kepada pemahaman yang menyesatkan (the corruption of knowledge). Dalam konteks ini, patut diberikan apresiasi yang mendalam atas perilaku ilmiah Michael H. Hart, penulis buku 100 tokoh berpengaruh dunia, yang menempatkan Rasulullah saw. pada urutan pertama, sejak zaman Yunani kuno hingga modern. Menurutnya, Muhammad saw. seorang pemimpin yang sukses dalam kepemimpinannya, baik secara individual, sosial, dan spiritual sehingga layak menempati posisi pertama. Sikap obyektif semacam itu dalam kapasitas sebagai seorang intelektual membuatnya tidak ragu menempatkan Nabi Muhammad saw. pada urutan "bergengsi" 5. Penilaian objektif semacam itu, didasarkan pada kajian panjang yang mendalam terhadap sosok Nabi Muhammad saw. apabila doktrin jihad yang diajarkan Muhammad bermakna negatif, tidak mungkin dia ditempatkan pada urutan pertama dari 100 orang terkemuka.

Sikap serupa juga ditunjukkan John L. Esposito yang berkesimpulan bahwa Islam (dengan doktrin jihadnya) bukanlah ancaman bagi dunia Barat dan Amerika pasca Perang Dingin. Dia memandang Islam merupakan mitra dalam membangun peradaban dunia. Pendapat ini dengan sendirinya membidas dan menggilas tesis yang dikemukakan oleh Samuel P. Huntington dalam tesisnya - the clash of civilizations and the remarking of world order-yang mengatakan Islam adalah ancaman serius bagi dunia Barat terutama Amerika.

\footnotetext{
${ }^{5}$ Buku ini aslinya berjudul The 100: A Ranking of The Most Influential Persons in History, diterbitkan pertama kali di New York pada tahun 1978. Karya monumental ini telah diterjemahkan ke dalam bahasa Indonesia oleh Karisma Publishing Group pada tahun 2005.
} 


\section{Aplikasi Makna Jihad dalam Realitas}

Bertolak dari makna jihad baik secara bahasa maupun istilah di atas, maka dapat dijadikan sebagai "intro" untuk memaknai jihad dalam makna sesungguhnya, agar umat saat ini tidak dibingungkan oleh terminologi jihad dan bentuk aplikasi sesungguhnya.

Secara historis, semenjak diizinkannya jihad dalam Islam, dapat dikatakan bahwa Islam pada dasarnya ingin tumbuh laiknya agama lain, seperti agama Yahudi dan Nasrani. Terlebih lagi, jika Islam dilihat sebagai satu rangkaian dari agama Samawi sebelumnya. Islam melalui doktrin jihadnya datang sebagai sebuah alternatif bagi tatanan masyarakat jahiliyah yang masa itu menyembah batu dan hawa nafsu. Kedatangannya atas pertolongan Allah dengan penuh kebenaran, serta berupaya mengikis habis segala bentuk kezaliman maka dipeluk beramairamai oleh bangsa Arab Quraisy. Al-Qur'an membahasakan mereka, pada saat mereka masuk Islam dengan kata afwaja' (berbondong-bondong), seperti yang tertera dalam Qs. al-Nashr (110): 2 .

Sejarah membuktikan bahwa kehadiran Islam dengan berbagai tawaran alternatifnya, termasuk realisasi doktrin jihad, membuat banyak pihak tersinggung dan marah, sehingga terjadilah barbarisasi semisal intimidasi, pemerkosaan, pembunuhan, perampasan harta, pemboikotan, dan pengusiran yang berujung hijrah ke Madinah (Yatsrib). Segala bentuk perlakuan musuh tersebut dapat menggambarkan kenestapaan yang dialami umat Islam di bawah pimpinan Nabi Muhammad saw. Perlakuan kasar musuh tidak berhenti di sana, tetapi berlanjut sampai ke Madinah, terutama bagi kaum muslimin yang masih berada di kota Mekkah setelah ditinggal hijrah oleh Nabi Muhammad saw.

Pada saat itu, salah satu upaya untuk penyeimbangan keadaan, maka Allah "mengizinkan" untuk memberikan 
perlawanan terhadap kuffâr Quraisy. Hal itu diabadikan dalam firman Allah yang berbunyi:

\section{أذن للذين يقاتلون بأنهم ظلموا و إن الله على نصر هم لقدير.}

Artinya: "Telah diberikan izin kepada orang-orang yang diperangi, bahwa mereka dizalimi, dan sesungguhnya Allah maha kuasa untuk memenangkan mereka". ${ }^{6}$

Legalitas jihad semacam ini, diberikan untuk meminimalisasi kebatilan dan kesewenang-wenangan (baca: despotisme), serta menegakkan syariat Allah dari kekejaman kuffâr Quraisy pascahijrah. ${ }^{7}$ Berkaitan dengan hal di atas, perlu diingat bahwa perang Badar sebagai salah satu aplikasi jihad diawali oleh sekedar keingingan kaum muslimin di kota Madinah menghadang kafilah Abû Sufyân yang baru datang dari Syam, guna mengambil harta mereka yang dirampas di kota Makkah. Namun maksud tersebut tercium oleh kuffâr Quraisy di Makkah dan kaum muslimin dianggap sebagai upaya penyerangan. Pada saat itu kaum muslimin yang bersama Rasulullah saw. tidak memprediksi jika kemudian penghadangan itu berujung pada perang (jihad). ${ }^{8}$

Jadi, jihad bertujuan untuk menghilangkan rintangan fisik yang menghambat kemajuan Islam dan umatnya. Dari itu, merupakan keniscayaan dalam menjalankan jihad dengan menyebarkan pemikiran tentang universalatas Islam dalam segala lini lewat diskusi ilmiah dan sejenisnya, agar orang dapat memiliki alternatif, opsi dalam keyakinan (theology option), dan dapat secara objektif melihat Islam (jihad). Hal ini dilakukan, karena sasaran jihad adalah berpikir objektif karena berpikir dengan menggunakan akal sehat seorang dapat menentukan pilihan dan ideologi mana yang akan dianutnya.

${ }^{6}$ Qs. al- $\underline{\mathrm{H}} \mathrm{ajj}$ (22): 41

${ }^{7}$ Shafî al-Rahmân al-Mabârak Fawrî, Al-Rabîq al-Makbtûm: Sîrab Nabawiyyah (Beirut Libanon: Muassasah al-Târîkh al-'Arabî, 1416 H/1996M), 184-6.

${ }^{8}$ Ibid., 194. 
Islam dengan semangat jihadnya berkeinginan untuk mengekspresikan nilai-nilai yang terkait dengan kemanusiaan, demokrasi, toleransi, dan keadilan sehingga orang dapat menilai bahwa sesungguhnya tidak ada paksaan untuk memeluk Islam. Namun demikian, Islam dengan segala perangkatnya adalah dapat dijadikan objek kajian orang untuk diketahuinya. Dengan sikap ini orang yang ingin mengetahui Islam memiliki opsi dalam memenuhi ruang keyakinannya dan menjalankan syariatnya. Dan terhadap orang yang telah dengan sadar memeluk Islam, jika bersikap mengabaikan kewajiban maka di situ baru ada teguran keras agar kembali kepada keyakinan dan akidahnya yang benar. ${ }^{9}$

Salah satu jalan untuk memajukan Islam adalah jihad dengan senjata dalam rangka melawan musuh baik yang datang dari luar atau dalam, akan tetapi ia bukanlah solusi yang terdepan, seperti dalam kasus Perang Badar, yaitu penghadangan kafilah umat Islam yang berujung terjadinya perang yang tidak diduga.

Masih dalam koridor pemberian izin di atas, perintah perlawanan yang dilakukan sebagai tindakan penyeimbang terhadap apa yang dilakukan pihak musuh yang diperangi adalah sebuah perlawanan perang yang wajib terhadap orang yang melakukan penyerangan atas kaum muslimin. Perintah perlawanan menjadi wajib karena ia sebagai penyemimbang, sesuai perlakuan musuh, dalam batas-batas teritorial dan waktu dibolehkan berperang. ${ }^{10} \mathrm{Hal}$ tersebut dijelaskan dalam al-Qur'an:

"Dan berperanglah di jalan Allah, orang-orang yang memerangimu dan janganlah melampui batas. Sesungguhnya Allah tidak suka kepada orang yang melampui batas. Dan perangilah mereka di manapun kalian temukan mereka, dan usirlah mereka dari tempat kalian diusir, sesungguhnya fitnah (kesyirikan) lebih besar dosanya dari pada membunuh, dan janganlah kalian perangi mereka di Masjid al-Haram, sampai mereka memerangi kalian di situ. Jika mereka mulai menyerang

9Sayyid Quthb, Kekuatan Lailaha Illallah dalam Jihad, ter. Husni Abar (Solo: Ramdhani, Nopember 1992), 82.

${ }^{10}$ Fawrî, Sîrah..., 191-2. 
di Masjid al-Haram, maka perangilah mereka, yang demikian itu balasan bagi orang kafir. Jika mereka berhenti menyerang, sesungguhnya Allah Maha Pengampun lagi Maha Penyayang. Dan perangilah mereka sehingga tidak ada lagi fitnah (kesyirikan) dan agama hanyalah untuk Allah. Jika mereka berhenti maka tidak ada permusuhan kecuali atas orang-orang yang zhalim."11

Dari penjelasan ayat di atas, dapat ditegaskan bahwa jihad dalam Islam akan dapat ditegakkan, apabila pihak lain memulai dengan kekerasan dengan cara perlawanan yang setimpal dan tidak boleh berlebihan atau melampui batas serta ada di area dan waktu yang tak terlarang. Dari itu, jihad merupakan bentuk perlawanan yang bersifat pembelaan yang dilakukan dengan syarat dan cara yang sangat ketat sehingga dapat dikatakan atau dikomandangkan: "jihad akan berkobar". Hal ini dilakukan jika pihak Asing dan lainnya melakukan penyerangan dan intimidasi terhadap Islam, atau menerapkan standar ganda, dan berlaku tidak adil terhadap Islam.

Berkaitan dengan di atas, dalam melakukan jihad perang, hal yang sering dilupakan dan diperhatikan bahwa saat jihad dilakukan harus mengedepankan etika dan tata cara yang tidak boleh dilanggar. Di antaranya, saat serangan hendak dilakukan, pasukan diperintahkan untuk memberikan opsi dan penawaran, opsinya adalah masuk Islam, jika tidak, bayar upeti, jika tidak, barulah peperangan dimulai. Saat pilihannya jaduh pada perang, ada etika yang harus tetap dijunjung para prajurit muslim, yaitu hanya memerangi mereka yang memerangi kaum muslimin, tidak boleh mutilasi (mencincang musuh yang terbunuh), tidak boleh membunuh wanita, orang tua jompo, anak-anak, tidak boleh menghancurkan bangunan, mematahkan jembatan, menebang pohon, dan lainnya. Hal ini diisyaratkan dalam sebuah hadis Rasulullah yang berbunyi:

${ }^{11}$ Qs. al-Baqarah [2]: 190-193. 


\section{عن عبد الله بن يزيد الأنصاري رضي الله عنه قال:نهى رسول الله صلى الله عليه

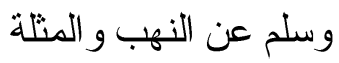

Artinya: "Dari 'Abd al-Lâh bin Yazîd Al-Anshârî dia berkata: Rasulullah saw. melarang merampas dan menghancurkan harta, dan melarang mencincang (mutilasi) musuh."12

Selain itu, ada hadis yang memberikan isyarat tetang tidak boleh melakukan mutilasi, yaitu hadis yang berbunyi:

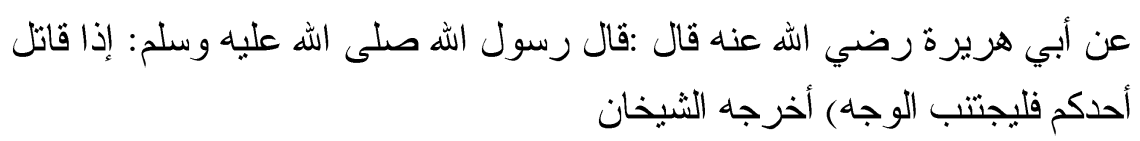

Artinya: Dari Abû Hurayrah dia berkata: Rasulullah saw. bersabda: "Apabila salah serorang di antara kalian berperang, maka hendaklah menghindari wajah (tidak memukul di wajah)."13

Selanjutnya semua tingkatan dan jenis jihad berserta segala makna yang dikandungnya bila dikaitkan dengan apa yang terjadi di Palestina, maka cukuplah bagi seorang untuk dijadikan kenyataan makna jihad dalam realita kehidupan. Rakyat Palestina sejak Israel menjajah bangsa itu, semua bentuk perlawanan dilakukan, mulai dari penyiapan para prajurit handal dan ikhlas dalam berjuang, sampai mereka dibombardir termasuk pemukiman mereka oleh Israel. Walaupun demikian, mereka melakukan pengajaran ilmu kepada anak bangsanya. Mereka mengkritik standar ganda, kesewenang-wenangan, dan kebijakan negara Barat yang tidak adil terhadap mereka. Semangat jihad mereka tetap berkobar juga walaupun dengan politik dan pemilihan parlemen. Dalam hal pemilu mereka memenangkan dan mengalahkan kekuatan "Fatah" yang lebih memilih kompromi dengan Israel dan sekutunya. Di sana Hamas dan bangsa Palestina paham bahwa dunia tidak mendukungnya dalam banyak hal sehingga ditempuhnya jalur politik untuk

12al-Bukhârî., Shahihh al-Bukhâri, (Bairut: Dâr al-Fikr, tt), 445.

${ }^{13}$ Ibid, 446. 
mendapat legitimasi atas perjuangannya yang panjang dan melelahkan. Namun sayang, yang mereka dapatkan adalah ketidakadilan, karena Israel selalu di pihak yang menang meski bersikap "tidak fair" dalam permainan politik dan kebijakan. ${ }^{14}$

Apa yang dilakukan Hamas sebagai upaya jihad dalam rangka melawan Israel adalah perjuangan terpuji, walaupun Hamas sangat memahami marâhil (fase-fase) dalam jihad dan bentuk yang akan digunakan pada setiap marbalah (fase) itu. Setelah menggunakan berbagai tahapan, mereka mengedepankan jalan damai melalui serangkaian kerja politik seperti ikut dalam pemilu parlemen, yang merupakan kehendak negara Barat dan Eropa. Akhirnya, mereka memenangkan pemilu dengan cara yang sangat demokratis, meski mendapatkan pemantauan dari orang Amerika sendiri seperti Jimmy Carter. Tapi sayang, jihad politik Hamas dan Palestina ini disikapi dengan standar ganda dan penuh kezaliman oleh musuh-musuh mereka.

Selain itu, sebagai sikap tidak baik terhadap Palestina dan Hamaa, Israil mengajukan berbagai syarat yang harus dipenuhi untuk mendapatkan pengakuan dunia dan bantuan logistik. Semua syarat itu tidak menguntungkan bagi Palestina, hanya menguntungkan Israel dan Amerika serta sekutu-sekutunya. Di antaranya adalah agar Palestina mengakui eksistensi Israel, namun Hamas tetap bersikukuh dengan pendiriannya yang tidak mau mengakui eksistensi Israel, karena bagi Hamas dan Palestina, segudang syarat sebelumnya telah dipenuhi oleh Palestina seperti perjanjian yang ditandatangani antara lain: perjanjian Oslo, Madrid, dan Syeikh Syarm yang semuanya dikhianati oleh Israel, dan tetap saja sampai hari ini kebiadaban Israel tak dapat dihentikan, malah cenderung dilindungi. Jika kemudian ada kesepakatan baru lagi pasca Hamas memimpin Palestina, apakah ada jaminan Israel akan mematuhi semua

${ }^{14}$ Amrozi M. Rois, "Direktur Center Middle East Studies (COMES) Jakarta: Siapa yang Tahu Hukum, Palestina atau Israel?”, Republika, Rubrik Opini, Sabtu, 11 November 2006 ), 6. 
perjanjian itu? Sesungguhnya ini adalah kezhaliman, dan siapakah sejatinya yang tahu hukum Israel atau Palestina? Tanya Amrozi. ${ }^{15}$

Kemenangan Hamas dalam pemilu parlemen, disebabkan keberhasilan mereka melaksanakan jihad lain seperti, pendidikan, keberaniannya dalam mengkritik bahkan melawan kebijakan presiden Palestina terdahulu (sebagai upaya kontrol). Jihad juga dilancarkan Hamas di bidang ekonomi, sehingga mampu meraih simpati masyarakat Palestina, melalui program ekonominya.

Sesungguhnya jihad dalam Islam tidaklah terbatas pada peperangan dengan pedang, tombak, atau panah, tetapi lebih luas dari itu. Jihad mencakup semua usaha yang dikeluarkan untuk menegakkan kalimat Allah, memerangi hawa nafsu untuk meninggalkan maksiat dan membiasakan taat, belajar dan mengajar ilmu, mengasah otak untuk mencapai penemuan baru yang tidak kita ketahui sebelumnya, menolong prajurit yang bertempur dan keluarga yang ada di belakang mereka, amar makruf dan nahi mungkar, sabar dalam sakit, bahkan menghadirkan niat jihad dan sebagainya. ${ }^{16}$

Urutan jihad yang pertama adalah pengingkaran hati, dan puncaknya adalah berperang di jalan Allah. Di antara keduanya ada jihad dengan lisan, pena, tangan, dan kata-kata yang benar di hadapan penguasa yang zhalim. Untuk memperjelas adanya tingkatan dan urutan jihad, dapat direnungkan firman Allah swt. dalam Qs. al-Tawbah [9]: 122 yang artinya: "Tidak sepatutnya bagi kaum beriman, berangkat semuanya kemedan tempur, hendaklah ada beberapa orang dari kelompok mereka ada segolongan, tafaqquh (memperdalam pemahaman) agama, setelah itu mereka memberikan peringatan kepada kaumnya apabila mereka telah kembali dari menuntut ilmu kepada mereka, agar kaum itu memiliki sikap berhati-hati”.

${ }^{15}$ Ibid.

${ }^{16}$ Sayyid Muhammad Nuh, Cara Rasulullah saw Mengobarkan Semangat Jihad, pen. A Badruddin (Solo: Media Insani Press, Nopember 2004), 148. 
Ayat tersebut menjelaskan ada dua jenis jihad yang hendak dilakukan dalam waktu yang sama. Pertama, jihad dengan senjata, dan kedua, jihad dengan menuntut ilmu (jihâd al-ta'lim). Jihad dengan senjata tidak diwajibkan kepada semua kaum mu'min. Karena itu, jihad dengan senjata hukumnya fardlu kifâyah, artinya jika sebagian orang menunaikan kewajiban ini, maka kewajiban yang lain menjadi gugur. ${ }^{17}$

Dalam beberapa hadis Rasulullah dijelaskan bahwa jihad itu hampir sama dengan ibadah haji, sebagaimana hadiss yang diriwayatkan dari Abû Hurairah: Bahwa jihadnya kaum wanita, orang tua, dan orang lemah adalah haji”. Dalam hadist lain juga dijelaskan bahwa jihad paling mulia adalah menyuarakan kebenaran di hadapan penguasa yang zhalim, dan demikian juga dikenal dalam perpolitikan, yang disebut dengan istilah jịhâd siyâsî (politik). Di samping itu, dalam ulasan para ulama tentang jihad diberikan penjelasan bahwa jihad ada beberapa jenis, dan diaplikasikan sesuai kebutuhan dan kondisi riil. Jadi, tidak benar jika disebut kata jihad, lantas memori langsung tertuju pada hunusan pedang dan ledakan bom.

Selanjutnya, berkaitan dengan jihad, maka apa yang menjadi

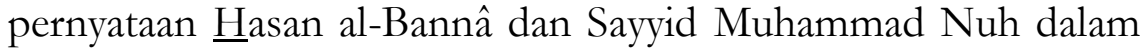
bukunya adalah penting untuk diperhatikan, di mana mereka mendukung apa yang telah terulas pada pembicaraan sebelumnya bahwa berjihad dengan senjata bukan solusi awal dan pertama. Aplikasi jihad dengan senjata sangatlah kondisional, karena ada tingkatan jihad dan marhalah yang berbeda sehingga penerapannya sesuai dengan zhurûf (kondisi). Karena itu, jenis jihad yang mana yang akan dioperasionalisasikan, tergantung pada kondisi dan situasi yang mengitari saat itu.

${ }^{17} \mathrm{Al}-\mathrm{Maqdis} \hat{1}$, Al-'Tddah..., 647. 


\section{Kesalahpahaman tentang Jihad}

Kesalahan dalam memahami doktrin-doktrin dalam Islam berawal dari kurangnya pemahaman, dan minimnya referensi yang diacu, termasuk juga dalam masalah jihad. Dalam hal ini, jangankan orang lain (nonmuslim), kaum muslimpun banyak juga memiliki pemahaman yang minim tentang jihad dalam arti sebenarnya, bahkan hal ini terjadi pada orang yang mengklaim diri sebagai pejuang muslim, da'i, dan sebagainya. Sikap mengakui sebagai orang yang mengetahui makna jihad padahal ia pada dasarnya tidak tahu adalah sikap yang tak terpuji. Sikap semacam ini diingatkan oleh Allah swt. (bahkan dengan celaan) melalui firman-Nya: "Janganlah ikuti sesuatu yang kamu tidak memiliki ilmunya. Sesunggubnya pendengaran, penglibatan dan bati semuanya akan diminta pertanggungjawabannya." (Qs. al-Isrâ' [17]: 36).

Kesalahpahaman seorang dalam memahami makna jihad masih dapat diperbaiki jika murni disebabkan ketidaktahuannya. Namun, jika kesalahpahaman tersebut didasari pada atau berangkat dari ideologi tertentu, maka hal semacam ini perlu "diwaspadai" dan diklarifikasi. Bentuk kesalahan dalam pemahaman ini diperparah oleh berbagai motif: ekonomi, politik, bahkan dendam kesumat sehingga sulit untuk mengubah image yang salah itu.

Di antara kesalahpahaman yang mesti diwaspadai dan diklarifikasi adalah memaknai jihad sebagai suatu prinsip pemaksaan, dalam arti bahwa Islam ingin memaksa orang lain untuk masuk dan ikut Islam secara paksa dan melalui pedang (perang). Karena pemahaman semacam ini tidak selaras dengan ajaran Islam sendiri, karena Islam menolak iman imitasi yang lahir tanpa melalui proses penalaran rasional, proses penyadaran, dan pilihan yang bebas. Sikap pemaksaan ini dikecam dalam alQur'an sesuai dengan firman Allah dalam Qs. Yûnus [10]: 99,"Apakah kalian hendak memaksa manusia supaya mereka menjadi orang-orang yang beriman semuanya", dan Qs. al-Baqarah [2]: 256, 
"Tidak ada paksaan dalam agama, sesunggubnya telab jelas jalan yang benar dan jalan yang salab".

Makna jihad sesungguhnya dalam Islam sangat mulia, yaitu membendung serangan musuh, menghilangkan kezaliman yang dilakukan oleh para pengusa diktator. Intinya mengeluarkan manusia dari segala bentuk "penghambaan" kepada selain Allah dan mengeluarkan mereka dari terasa sempitnya dunia menuju luasnya Islam, dan menjauhkan kaum muslimin dari segala bentuk kezaliman dari dalam maupun luar menuju keadilan Islam.

Kesalahpahaman yang nyata adalah apa yang terjadi di dunia Barat di mana sejak tahun 2000-bahkan saya yakin juga sejak dahulu kala—di mana jihad di mata dunia Barat dan Amerika cenderung disalahpahami, yang diidentikkan dengan terorisme, yang kemudian dijadikan "amunisi" untuk menyudutkan kaum muslimin dunia. Sebagai contoh term "teroris" yang disamakan dengan muslim yang taat beribadah, rajin membaca al-Qur'an, orang baik, dan sebagainya. Keterlibatan orang muslim yang soleh, Usamah bin Laden, dengan terorisme semisal kejadian peledakan gedung WTC (world trade center) pada tanggal 11 September 2001, belum bisa dibuktikan sampai saat ini, karena yang ada baru praduga yang tidak didukung oleh fakta. Oleh karena itu, sesungguhnya, isu terorisme yang dikampanyekan Amerika dan sekutu-sekutunya, tidak lebih dari agenda untuk memuluskan kepentingan politik dan ekonomi luar negeri mereka.

Berkaitan dengan sikap AS dan sekutunya maka menurut Aukai Collins ${ }^{18}$ sebagai salah seorang agen CIA dan FBI adalah sikap yang tak terpuji, sebagaimna ungkapannya:

"Pemerintah Amerika Serikat tidak mungkin dapat menyelesaikan

${ }^{18}$ Aukai Collins adalah muallaf berasal dari San Diego, California Amerika Serikat. Ia masuk Islam di dalam penjara ketika menjalani hukuman karena aksi premanisme yang kerap dilakukannya. Ia juga pernah dipekerjakan dalam misi kontra intelejen bersama FBI dan CIA. 
ancaman teroris, sampai pemerintahannya memahami semua ancaman yang dipaksakan Kristen, Yahudi, dan kelompok nonrelejius. Aku telah mengalami pertempuran digaris depan dalam jihad di beberapa negeri seberang, dan aku juga memiliki pengalaman kontra intelejen di Amerika sebagai agen CIA dan FBI. Tetapi selama bertahun-tahun pemerintah Amerika mengabaikan Islam, dengan sikap mereka yang paranoid dan xenophobia. Filsafat rasis telah mengarahkan kita ke saluran visi-diri kekerasan, serupa dengan ketakutan atas komunisme di amerika pada era 1950-an. Pengalamanku bersama CIA dan FBI telah meyakinkanku bahwa mereka tidak hanya memiliki mentalitas "pemburu-sihir" yang menyimpang, tetapi juga agenda yang membuat mereka menjauhi problem nyata dari ancaman teroris internasional dan menyebabkan pelecehan terhadap martabat individual di antara komunitas muslim Amerika. Sebagaimana anda lihat, aku mencoba menunjukkan kepada FBI maupun CIA, bagaimana menginfiltrasi sel teroris di AS dan mancanegara, namun para birokrat itu tidak punya kemampuan dan keinginan untuk melawan dan membendung elemen teroris atas nama Islam, di mana saja. Mereka tidak ingin anda mengetahui bahwa tidak ada perang yang sebenarnya melawan terorisme. Mereka tidak ingin anda mengetahui bahwa sebagian dari pembajak pesawat dalam serangan 9/11 telah diketahui oleh FBI sejak tahun 1999, sekarang lebih banyak lagi orang yang perlu mengetahui fakta, bahwa kesalahpahaman dan ketakutan tidak akan menghasilkan apa-apa, kecuali menghancurkan kita" 19

Intisari pernyataan Aukai Collins adalah terorisme yang disematkan Amerika kepada Islam, ternyata faktanya ada pada Kristen, Yahudi, dan kolompok nonreligius. Penyematan terorisme dan jihad merupakan bagian dari ketidakadilan Amerika terhadap Islam yang dihinggapi penyakit paranoid dan xenophobia. Hebatnya lagi, Aukai Collins mengatakan: "perang terhadap terorisme sebagai mentalitas pemburu-sihir, yang tentu merugikan umat Islam”. Di satu sisi Amerika juga tidak mampu dan tidak ingin melawan dan membendung elemen teroris di mana saja. Yang lebih naif lagi ada hal yang ditutup-tutupi

${ }^{19}$ Aukai Collins, My Jihad on American's Mujahid Journey (New York: Pocket Star Books, Februari 2003), xxii-iii. 
mengenai pembajakan pesawat 11 September 2001, justru FBI sudah tahu rencana ini sejak tahun 1999 dan tidak ada perang terhadap terorisme yang dikampanyekannya dan diindikasikan sebagai jihad atau perang suci dalam Islam yang diterjemahkan oleh mereka. Penerjemahan yang demikian itu merupakan upaya fitnah keji terhadap Islam, dengan menyematkan terorisme sebagai bagian dari Islam dan diindentikkan dengan jihad dan perang suci, padahal jihad dengan senjata dilakukan dengan berbagai pertimbangan dan cara yang sangat prosedural, bukan dalam bentuk pengerusakan seperti apa yang dilakukan Amerika terhadap Irak, Palestina, Afganistan, dan lainnya.

\section{Jihad dengan Angkat Senjata}

Saat penerapan jihad dengan senjata, Islampun memberikan syarat dan tahapan; antara lain tahapan mempersiapkan personal mujahid yang baik, bertindak dengan ilmu, memiliki etika dalam perang, dan medan laga. ${ }^{20}$ Saat jihad dilakukan, harus dipastikan bahwa kaum muslimin tidak memulai menyerang, tapi pihak luar yang memulai serangan dan melakukan tindakan keji dan serangan itu telah menorobos negeri muslim dari berbagai arah. Pada saat itulah, jihad dengan senjata wajib bagi kaum muslimin. Bila keadaan dapat kuasai oleh muslim, maka kaum muslim dapat memberikan opsi kepada lawan perang, yaitu, pertama, mereka diajak masuk Islam. Jika enggan masuk Islam, maka diharuskan untuk membayar jizyah atau upeti. Kedua, jika tetap menolak kedua opsi tersebut, maka mereka diperbolehkan untuk diserang. Pada saat perang berlangsung, terdapat beberapa ketentuan, antara lain; tidak boleh membunuh anak-anak, orang gila, wanita, orang tua, menebang pohon, menghancurkan jembatan dan bangunan, tempat ibadah, tidak boleh melakukan

${ }^{20}$ Nuh, Cara..., 128-34. 
mutilasi (mencincang musuh), dan memerangi yang hanya memerangi Islam dan kaum muslimin. ${ }^{21}$

Berkaitan dengan hal di atas, sangat tidak beralasan kalau jihad yang begitu indah, dikatakan sebagai sebuah kekerasan, atau dipersepsi salah. Jika dicerna lebih mendalam, sesungguhnya ada nilai kedamaian dalam jihad, karena jihad dilakukan dengan cara dan prosedur yang sangat rapi dan ketat. Dengan demikian, dapat dikatakan bahwa jihad itu idealnya melahirkan kedamaian untuk masyarakat muslim khususnya dan umat manusia pada umumnya. Sungguh disayangkan, jika hal tersebut disalahartikan (misunderstanding).

Diharapkan semua umat belajar melihat sesuatu dengan kaca mata ilmu, bukan persangkaan, dan melakukan tabayyun (recheck) sebelum mewacanakannya. Karena akibatnya sangat fatal jika itu tidak dilakukan, yaitu mengakibatkan keburukan atas suatu kaum: "Wahai orang beriman, jika datang kepada kalian seorang yang fasik dengan sebuab berita, maka periksalab kebenaran beritanya, karena ketidaktahuan itu akan mengakibatkan kerugian bagi suatu kaum, dan kalian menjadi menyesal atas perbuatan kalian." (Qs. al- Hujurât [49]: 6).

\section{Catatan Akhir}

Jihâad adalah upaya terakhir untuk menyatakan bahwa Islam tidak suka ditekan, tidak suka diperlakukan tidak adil, jihad bertujuan mengeluarkan manusia dari penghambaan kepada sesama manusia, menuju hanya menghamba kepada Allah, mengeluarkan manusia dari kezaliman agama-agama, menuju keadilan Islam, dan mengeluarkan manusia dari sempitnya dunia menuju keluasan Islam. Jihad dapat dilakukan dengan berbagai syarat dan tujuan, yang menjadikannya jauh dari sebuah ajaran ofensif yang terkesan keras, justru kedamaian, karena kegiatan militer yang ada di situ, hanya sekedar pembelaan diri

${ }^{21}$ Al-Maqdisî, Al-'Tddah ..., 647. 
(melakukan upaya pembelaan terhadap agama, harga diri, dan keberlangsungan hidup) dan bukan jihad, jika keluar dari syarat dan ketentuannya yang sebenarnya.

Lalu mengapa jihad dianggap tindakan teror dan orang yang berjihad dikatakan teroris? Menurut penulis, justru jihad ingin menghadirkan kedamaian bagi umat manusia dan semesta, dengan syarat pihak lain jangan memulai permusuhan dengan Islam dan umatnya.

\section{Daftar Pustaka}

Amrozi M Rois, "Direktur Center Middle East Studies (COMES) Jakarta: Siapa yang Tahu Hukum, Palestina atau Israel?", Republika, Rubrik Opini, Sabtu, 11 November 2006).

Attabik Ali dan Ahmad Zuhry Mahdhar, Kamus al-'Ashrî (Krapyak Yogyakarta: Multi Karya Grafika, 1998).

Aukai Collins, My Jihad one American's Mujabid Journey (New York: Pocket Star Books, Februari 2003).

Bahâ' al-Dîn 'Abd al-Rahmân bin Ibrâhim al-Maqdisî, Al-Tdah

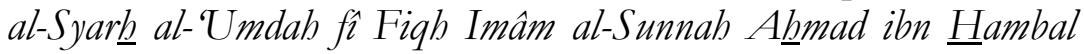
al-Syâf'ì (Beirut: Dâr al-Kitâb al-'Arabî, 1414 H/1994).

Hasan Al-Banna, Surat Terbuka untuk Kader Dakwah, ter. Khozin Abu Faqih (Jakarta: Al-I'tishom, 1992).

Luis Ma'lûf, al-Munjid fî al-Lughah (Beirut: Dâr al-Masyriq, 1977).

Shafî al-Rahmân al-Mubârak Fawrî, Al-Rahîq al-Makbtûm:Sîrah

Nabawiyyah (Beirut: Muassasah al-Tarîkh al-'Arabî, 1416 $\mathrm{H} / 1996 \mathrm{M})$.

Sayyid Muhammad Nuh, Cara Rasulullah saw. Mengobarkan Semangat Jihad, ter. A Badruddin (Solo: Media Insani Press, Nopember 2004).

Sayyid Quthb, Kekuatan Lailaha Illallah dalam Jihad, ter. Husni Abar (Solo: Ramdhani, Nopember 1992).

Yusuf Al-Qardhawi, Menuju Kesatuan Fikrah Aktivis Islam, ter. A.

Najiyullah (Jakarta: Robbani Press, Agustus 1993). 